\title{
Evaluation of Relatively constant factors in Preparedness of Disaster Management in Riyadh City, Saudi Arabia
}

\author{
1,2AL Garni A. Mohammad, 3Awadelkarim M. Ali, ${ }^{4}$ Alhijan A. Ahmad
}

${ }^{1}$ Member of the Saudi Society for Geosciences

${ }^{2}$ nstitute of Environmental Studies, University of Khartoum, Khartoum, Sudan

${ }^{3}$ Faculty of Medicine, University of Khartoum, Khartoum, Sudan

${ }^{4}$ The Shora Council, Riyadh, Kingdom of Saudi Arabia

Correspondence Author: AL Garni A. Mohammad, Member of the Saudi Society for Geosciences

E-mail:Al-garni@gmail.com; aaa1020@hotmail.com

Received date: 11 February 2018, Accepted date: 15 May 2018, Online date: 29 May 2018

Copyright: (C) 2018 AL Garni A. Mohammad et al. This is an open-access article distributed under the terms of the Creative Commons Attribution License, which permits unrestricted use, distribution, and reproduction in any medium, provided the original author and source are cre dited.

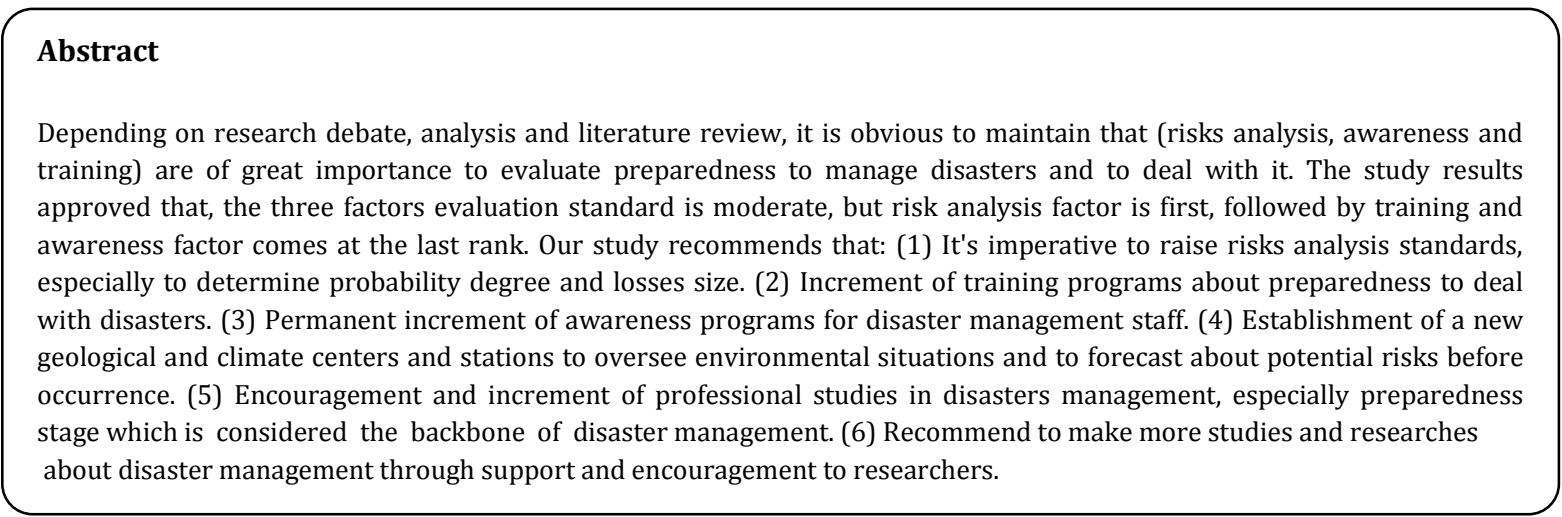

Key words: Disaster Management; Risks analysis; awareness; Training; Saudi Arabia.

\section{INTRODUCTION}

Disaster management is considered a new science in spite of disasters events occurrence in the past. Now all countries facing environmental disasters, some of these disasters are properly treated, while others failed because of the shortage of (risk analysis, training and awareness) and its relationship with disaster's management.

Environmental disasters is a source of danger to communities, it adversely affect balances of power at all levels (government, firms and individuals) which leads to false decisions and chaotic situations [6]. However environmental disasters can be controlled through effective disaster control systems, but its imperative to establish research unit as part of disasters management systems in order to guarantee a sound risk analysis.

Awareness is essential, so its important to plan, arrange and implement awareness programs to educate all community categories besides disasters management staff, Beside that, training is of great importance to deal with disasters on a scientific bases, this make disasters management achieve its targets.

Training helps community individuals to face disasters in a powerful way, also it in force staff's culture which in rich their experiences to deal with crisis and disasters, this increase individual responsibility towards their organization and homes.

Some procedures can be implemented to alleviate the impacts of environmental disasters. These can be implemented by coordinating efforts between governmental an nongovernmental institutions that interested in statistical and for casting [18] (issue and Actions, 2009).

Preparedness stage is considered as a backbone of disasters management and studies reveals that disasters negative effects are related to absence or low level of preparedness, for this reason the study problem concentrate on the effect of the relatively organized factors on preparedness of disasters management in order to prevent disasters or to alleviate its effects, so the study investigate the correlation between disasters management and risk analysis, coordination, follow up, awareness, training, human resources, financial resources and technical resources.

Therefore, the aim of study is o shade lights on three of the relatively organized factors and to investigate its effect on preparedness to manage disasters.

Methodology:

The study follows descriptive analytical approach and comprehensive survey by using statistical approach through making systematic layer sample from environment disasters management of Riyadh town which include 21 sector - study community size: 397 individuals with sample size equal to "353", - statistical styles "frequencies, percentage, standard deviation, chi- square, probabilities and Likert scale "are used to evaluate the effectiveness of relatively organized factor in preparedness of disaster management.

Research Hypothesis:

The study investigates the following hypothesis (there is a positive correlation between risk analysis, awareness, training and effective environment disaster management). 
The questionnaire distributed to include the demographic aspects of the research community "age, job years in environment disaster management, academic qualifications, and number of training course.

\section{RESULTS AND DISCUSSION}

Firstly: demographic factors can be shown in table (1)

$\underline{\text { Table 1: Depicts distribution of research community, sample size and percentage }}$

\begin{tabular}{|c|c|c|c|}
\hline Institution & Community size & Sample size & Percentage \\
\hline Civil defence & 43 & 36 & 10.2 \\
\hline Ministry of health & 30 & 26 & 7.4 \\
\hline General security & 35 & 26 & 7.4 \\
\hline Ministry of water & 13 & 13 & 3.7 \\
\hline Boundaries security & 19 & 15 & 4.2 \\
\hline Sabic company & 25 & 21 & 5.9 \\
\hline Saudi red crescent & 35 & 35 & 9.9 \\
\hline Mlekabdelaziz town for sciences and technology & 11 & 1 & 2.5 \\
\hline Industrial towns corporation & 7 & 7 & 2 \\
\hline Forecasting \& environment protection & 21 & 21 & 5.9 \\
\hline Ministry of agriculture & 27 & 25 & 7.1 \\
\hline Ministry of localities & 18 & 17 & 4.8 \\
\hline Jobail\&Yanbo royal society & 18 & 18 & 5.1 \\
\hline Rial way corporation & 18 & 16 & 4.5 \\
\hline General ports corporation & 9 & 8 & 2.3 \\
\hline Electricity company & 27 & 21 & 5.9 \\
\hline Ministry of transportation & 17 & 15 & 4.2 \\
\hline ministry of trade and industry & 7 & 7 & 2 \\
\hline Saudi natural life society & 5 & 5 & 1.4 \\
\hline Ministry culture and media & 8 & 8 & 2.3 \\
\hline Ministry of oil & 4 & 4 & 1.1 \\
\hline Total & 397 & 353 & 100 \\
\hline
\end{tabular}

Source: made by the researcher from field study data " 2015 "

Secondly: distribution of the study tool phrases on its factors table (2)

Table 2: Distribution of the study tool phrases on its three factor

\begin{tabular}{lll}
\hline \multicolumn{1}{c}{ factor number } & factor name & number of phrases \\
\hline first & risk analysis & 6 \\
forth & awareness & 6 \\
fifth & training & 6 \\
Total of phrases & 18 & $33.33 \%$ \\
\hline Source: & $100 \%$ & $33.33 \%$ \\
\hline
\end{tabular}

Source: made by the researcher - field study data " 2015 "

Thirds: percentage frequency distribution of the study community according to age table (3)

\begin{tabular}{lll}
\hline Age & number & percentage \\
\hline less than 25 & 4 & 1.10 \\
from 25-30 & 54 & 15.30 \\
from 31.35 & 71 & 20.10 \\
from 36-40 & 69 & 11.50 \\
from 41-45 & 71 & 20.10 \\
from 45-50 & 42 & 11.90 \\
from 50- & 42 & 11.90 \\
\hline
\end{tabular}

Source: made by the researcher - field study data "2005"

As shown in the table, the highest percentages are the three categories which ranging from 31-35 year and from 41-45 year " $20.10 \%$ ", and from $36-40$ year. After that come two categories from $46-50$ and from 50 year and more " $11.90 \%$ " lastly those whom their ages are less than 25 years " $1.10 \%$ ". according to the study sample, the majority of the disaster management staff their ages ranging from 31-45.

Froth: percentage frequency distribution according to work institution

\begin{tabular}{|c|c|c|}
\hline institution & number & percentage \\
\hline Civil defence & 36 & 10.20 \\
\hline Ministry of health & 26 & 7.40 \\
\hline General security & 26 & 7.40 \\
\hline Ministry of water & 13 & 3.70 \\
\hline Security Boundaries & 15 & 4.20 \\
\hline Sabic company & 21 & 5.90 \\
\hline red crescent society & 35 & 9.90 \\
\hline mlek abdulaziz town for sciences and technology & 9 & 2.50 \\
\hline Industrial towns corporation & 7 & 2 \\
\hline Forecasting \& environment protection & 21 & 5.90 \\
\hline Ministry of agriculture & 25 & 7.10 \\
\hline Ministry of localities & 17 & 4.8 \\
\hline Jobail\&Yanbo royal society & 18 & 5.10 \\
\hline Rial way corporation & 16 & 4.50 \\
\hline General ports corporation & 8 & 2.30 \\
\hline Electricity company & 21 & 5.90 \\
\hline Ministry of transportation & 15 & 4.20 \\
\hline
\end{tabular}


Citation: AL Garni A. Mohammad, Awadelkarim M. Ali, Alhijan A. Ahmad, 2018. Evaluation of Relatively constant factors in Preparedness of Disaster Management in Riyadh City, Saudi Arabia. Advances in Natural and Applied Sciences., 12(5): 14-20.

ministry of trade and industry

Saudi natural life society

Ministry of culture and media

Ministry of oil

Total

Source: made by the researcher - field study data " 2005 "

$\begin{array}{ll}7 & 2 \\ 5 & 1.40 \\ 8 & 2.30 \\ 4 & 1.10 \\ 353 & 100\end{array}$

The table shown that the highest percentage of the study sample belong to civil defence sector "10.20\%", Saudi red crescent society "9.90\%", ministry of health and general security "7.40\%", ministry of agriculture "7.10\%", forecasting \& environment protection and Sabic company "5.90\%", Jobail\&yonbo royal society " $5.10 \%$ ", localities sector " $4.80 \%$ ", rial way corporations " $4.5 \%$ ", ministry of transportation and boundaries security " $4.20 \%$ ", water sector " $3.70 \%$ ", Melk abdulaziz town for sciences and technology " $2.50 \%$ ", ports and information sectors " $2.30 \% "$, trade \& industry - industrial town corporation " $2 \%$ ", Saudi natural life society " $1.40 \%$ ", the best percentage is " $1.10 \%$ " of the ministry of oil.

Fifth: percentage frequency distribution according to current job.

Table 5: percentage frequency distribution "current job".

\begin{tabular}{lll}
\hline Job title & Number & Percentage \\
\hline General director & 25 & 7.10 \\
Administration manger & 62 & 17.60 \\
Department manager & 60 & 17 \\
Division manager & 117 & 33.10 \\
Other & 89 & 25.20 \\
Total & 353 & 100 \\
\hline
\end{tabular}

Source: made by the researcher - field study data "2005"

As shown in the table, the highest percentage from the study sample is division manager " $33.10 \%$ ", followed by others " $25.20 \%$ ", administration manager " $17.60 \% "$, department manager "17\%", the least percentage is for general director " $7.10 \% "$.

Sixth: percentage frequency distribution according to academic qualifications.

Table 6: percentage frequency distribution (academic qualifications)

\begin{tabular}{lll}
\hline Academic qualification & Number & Percentage \\
\hline Secondary & 23 & 6.50 \\
Diploma & 71 & 20.10 \\
Bachelor & 202 & 57.20 \\
Master & 46 & 13 \\
Ph. D & 11 & 3.10 \\
Total & 353 & 100 \\
\hline
\end{tabular}

Source: made by the researcher - field study data "2005"

From the table its clear to know that, the highest percentage is for bachelor candidates " $57.20 \% "$, diploma " $20.10 \% "$, master " $13 \%$ ", secondary certificate "6.50\%", the best percentage is for $\mathrm{Ph}$. D holders " $3.10 \%$ ".

Seventh: percentage frequency distribution according to experience.

Table 7: percentage frequency distribution "experience".

\begin{tabular}{lll}
\hline Experience in disaster management & Number & Percentage \% \\
\hline less than 5 years & 78 & 22.50 \\
from 5-10 years & 68 & 19.60 \\
from 11-15 years & 96 & 27.70 \\
from 16-20 years & 57 & 16.40 \\
from 21-25 years & 29 & 8.40 \\
from 25- & 19 & 5.50 \\
Total & 347 & 100 \\
\hline
\end{tabular}

Source: made by the researcher - field study data "2005".

The table shows that the highest percentage from the study sample are those whose their experience is ranging from 11-15 year " $27.70 \%$ ", followed by the second category whose their experience is less than 5 years " $22.50 \%$ ", then those from $5-10$ years " $19.60 \%$ ", followed by the forth category from $16-20$ years " $16.40 \%$ ", then from $21-25$ years " $8.40 \%$ ", the best percentage " $5.50 \%$ " is for experience ranging from 25 years or more. This percentage indicate to experience factor of the study sample individuals which made them able to evaluate preparedness of the environment disaster management.

Eighth: percentage frequency distribution according to the number of disasters courses.

\begin{tabular}{lll}
\multicolumn{1}{c}{ Training course } & Number & Percentage \\
\hline No Training course & 60 & 17 \\
Only one training course & 44 & 12.50 \\
$2-4$ courses & 107 & 30.30 \\
$5-7$ courses & 78 & 22.10 \\
$8-10$ courses & 33 & 9.30 \\
More than 10 training courses & 31 & 8.80 \\
Total & 353 & 100 \\
\hline
\end{tabular}

Source: made by the researcher - field study data " 2005 ".

The table reveal that the highest percentage from the study sample ranging from $2-4$ courses " $30.30 \%$ ", followed by the second group ranging from $5-7$ courses " $22.10 \%$ ", followed by one training group " $12.50 \%$ ", than $8-10$ courses " $9.30 \%$ ", then the least group who has more than 10 training courses " $8.80 \%$ ".

Ninth: percentage frequency distribution according to the kind of sector. 
Citation: AL Garni A. Mohammad, Awadelkarim M. Ali, Alhijan A. Ahmad, 2018. Evaluation of Relatively constant factors in Preparedness of Disaster Management in Riyadh City, Saudi Arabia. Advances in Natural and Applied Sciences., 12(5): 14-20.

Table 9: percentage frequency distribution acceding to sectors

\begin{tabular}{lll}
\hline Kind of sector & Number & Percentage \\
\hline public sector & 311 & 88.10 \\
private sect & 42 & 11.90 \\
Total & 535 & 100 \\
\hline
\end{tabular}

Source: made by the researcher - field study data "2005".

Its clear that the highiest percentage is belong to the public sector, " $88.10 \%$ ", followed by " $11.90 \%$ " of the private sector.

Firstly: risks analysis:

The study hypotheses includes eight factors, the first hypothesis include three factors, the first factor is risk, analysis which is ranging from the highest to the lowest level according to their averages.

Table 10: Percentage distribution for the first factor hypothesis

\begin{tabular}{|c|c|c|c|c|c|c|c|c|c|}
\hline Phrase & \multicolumn{2}{|c|}{ very weak degree } & \multirow{2}{*}{$\begin{array}{l}\begin{array}{l}\text { weak } \\
\text { degree }\end{array} \\
27\end{array}$} & \multirow{2}{*}{$\begin{array}{l}\begin{array}{l}\text { average } \\
\text { degree }\end{array} \\
149\end{array}$} & \multirow{2}{*}{$\begin{array}{l}\begin{array}{l}\text { high } \\
\text { degree }\end{array} \\
137\end{array}$} & \multirow{2}{*}{$\begin{array}{l}\begin{array}{l}\text { very } \\
\text { degree }\end{array} \\
37\end{array}$} & \multirow[t]{2}{*}{ high } & \multirow{2}{*}{$\begin{array}{l}\text { average } \\
3.50\end{array}$} & \multirow{2}{*}{$\begin{array}{l}\begin{array}{l}\text { standards } \\
\text { deviation }\end{array} \\
0.82\end{array}$} \\
\hline Important data available about & $\mathrm{C}$ & 3 & & & & & & & \\
\hline different disasters & $\%$ & 0.8 & 7.6 & 42.2 & 38.8 & 10.5 & & & \\
\hline data is available about probable & $\mathrm{C}$ & 7 & 36 & 140 & 134 & 36 & & 3.44 & 0.88 \\
\hline disaster & $\%$ & 2 & 10.2 & 39.7 & 38 & 10.2 & & & \\
\hline data is available about risky zones & $\mathrm{C}$ & 7 & 41 & 104 & 123 & 78 & & 3.63 & 1.01 \\
\hline & $\%$ & 2 & 11.6 & 29.5 & 34.8 & 22.1 & & & \\
\hline data is available about the & $\mathrm{C}$ & 24 & 127 & 137 & 52 & 13 & & 2.73 & 0.92 \\
\hline probability of risks occurrence & $\%$ & 6.8 & 36 & 38.8 & 14.7 & 3.7 & & & \\
\hline data is available about the & $\mathrm{C}$ & 61 & 137 & 111 & 34 & 10 & & 2.42 & 0.98 \\
\hline approximate size of losses & $\%$ & 17.3 & 38.8 & 31.4 & 9.6 & 2.8 & & & \\
\hline professional staff is available for & $\mathrm{C}$ & 13 & 56 & 159 & 105 & 17 & & 3.16 & 0.88 \\
\hline risks analysis & $\%$ & 3.7 & 16 & 45.4 & 30 & 4.9 & & & \\
\hline risks analysis factors & & & & & & & & 3.15 & 0.67 \\
\hline
\end{tabular}

Source: made by the researcher - field study data -2015

Risk analysis phrases are differ according to individuals "public \& private sector" evaluation. The first phrase is "data is available about risky zones", its average " 3.63 " and standards deviation " 1.01 ", the ratio of who give probability degree for high and very high degree is " $56.9 \%$ ". at the second degree the phrase "important data available about different disasters, its average " 3.50 " and standard deviation " 0.82 ".

Thirdly: comes the phrase "data is available about probable disasters, its average " 3.444 " and standard deviation " 0.88 ".

At the fourth rank, is the phrase "professional staff is available for risks analysis, its average " 3.16 " and standard deviation " 0.88 ".

Number five is the phrase "data is available about the probability of risks occurrence, it average " 2.73 " and standard deviation " 0.92 ".

At the last rank comes the phrase "data is available about the approximate size of losses", its average " 2.42 " and standard deviation " 0.9892 ".

When analyzing risk analysis factor results, we find that individuals evaluations for this factor in tits average equal to "3.15".

Chi - square and correlation "c" experiment:

The first factor of the first hypothesis revels that "there is a meaningful differences between disasters management and risks analysis - to know the study sample individuals views about this hypothesis, calculated chi - square was compared with chi-square value from the table. There is a measurable differences between sample individuals answers about the first factor phrases which stated that "there is a meaningful differences between disasters management and risks analysis, the calculated value of chi-square " 268.46 " is more than the tables value of chi-square " 9.48 ".

As shown above we can approve that there is a statistical differences between disasters management and risks analysis.

Table 11: Correlation

\begin{tabular}{|c|c|c|c|}
\hline & & $\begin{array}{l}\text { important data is available about } \\
\text { different disasters }\end{array}$ & $\begin{array}{l}\text { data is available about the probability } \\
\text { of risks occurrence }\end{array}$ \\
\hline \multirow[t]{5}{*}{ spearman's rho } & $\begin{array}{l}\text { correlation coefficient sig. (2- } \\
\text { tailed) }\end{array}$ & 1.00 & $426 * *$ \\
\hline & $\mathrm{N}$ & 353 & 0000 \\
\hline & correlation coefficient & $426^{* *}$ & 353 \\
\hline & sig. (2- tailed) & 000 & 1000 \\
\hline & $\mathrm{N}$ & 353 & 535 \\
\hline
\end{tabular}

** Correlation is significant at the 0.01 level (2. Tailed)

Table 12: Chi-square tests

\begin{tabular}{llll}
\hline & value & df & asymp. Sig. (2-sided) \\
\hline Pearson chi-square & 79.241 & 16 & .000 \\
Likelihood Ratio & 82.483 & 16 & .0000 \\
linear - by - linear association & 66.067 & 1 & .000 \\
N of valid cases & 535 & & \\
\hline
\end{tabular}

To know the correlation between disasters management and risks analysis, correlation table (11) and chi-square table (12), indicate that there is a significant effect between risks analysis and disasters management, that according to p. value 0.00 which is less than " 0.05 ".

This means that sound risk analysis leads to enforcement of preparedness of disasters' management - the result of that is the acceptance of the hypothesis.

Secondly: Awareness

Table 13: percentage distribution of the second factor of the hypothesis

\begin{tabular}{|c|c|c|c|c|c|c|c|c|}
\hline Phrase & & degree & $\begin{array}{l}\text { high } \\
\text { degree }\end{array}$ & $\begin{array}{l}\text { average } \\
\text { degree }\end{array}$ & $\begin{array}{l}\text { weak } \\
\text { degree }\end{array}$ & $\begin{array}{ll}\begin{array}{l}\text { very } \\
\text { degree }\end{array} & \text { weak } \\
\end{array}$ & average & $\begin{array}{l}\text { standards } \\
\text { deviation }\end{array}$ \\
\hline $\begin{array}{llll}\text { awareness } & \text { programs } & \text { about } & \text { different }\end{array}$ & $\mathrm{C}$ & 5 & 57 & 175 & 92 & 24 & 3.21 & 0.84 \\
\hline disasters are available & $\%$ & 1.4 & 16.1 & 49.6 & 26.1 & 6.8 & & \\
\hline awareness programs about preparedness & $\mathrm{C}$ & 22 & 112 & 146 & 62 & 11 & 2.80 & 0.91 \\
\hline are available & $\%$ & 6.2 & 31.7 & 41.4 & 17.6 & 3.1 & & \\
\hline
\end{tabular}

Advances in Natural and Applied Sciences

ISSN-1995-0772 EISSN-1998-1090 
Citation: AL Garni A. Mohammad, Awadelkarim M. Ali, Alhijan A. Ahmad, 2018. Evaluation of Relatively constant factors in Preparedness of Disaster Management in Riyadh City, Saudi Arabia. Advances in Natural and Applied Sciences., 12(5): 14-20.

\begin{tabular}{|c|c|c|c|c|c|c|c|c|}
\hline awareness programs about how to face & $\mathrm{C}$ & 41 & 108 & 149 & 43 & 12 & \multirow[t]{2}{*}{2.65} & \multirow[t]{2}{*}{0.95} \\
\hline disasters are available & $\%$ & 11.6 & 30.6 & 42.2 & 12.2 & 3.4 & & \\
\hline \multirow{2}{*}{ awareness programs are comprehensive } & $\mathrm{C}$ & 12 & 88 & 185 & 53 & 15 & \multirow[t]{2}{*}{2.92} & \multirow[t]{2}{*}{0.84} \\
\hline & $\%$ & 3.4 & 24.9 & 52.4 & 15 & 4.2 & & \\
\hline \multirow[t]{2}{*}{ awareness programs are enough } & $\mathrm{C}$ & 23 & 137 & 136 & 47 & 10 & \multirow[t]{2}{*}{2.67} & \multirow[t]{2}{*}{0.89} \\
\hline & $\%$ & 6.5 & 38.8 & 38.5 & 13.3 & 2.8 & & \\
\hline \multirow[t]{2}{*}{ awareness programs are good } & $\mathrm{C}$ & 12 & 73 & 191 & 66 & 11 & \multirow[t]{2}{*}{2.97} & \multirow[t]{2}{*}{0.81} \\
\hline & $\%$ & 3.4 & 20.7 & 54.1 & 18.7 & 3.1 & & \\
\hline awareness factor & & & & & & & 2.87 & 0.7 \\
\hline
\end{tabular}

Source: made by the researcher - field study data -2015

According to the table the ranking of phrases comes as follows,

1. "awareness programs about different disasters are available, "3.21" and " 0.84 " are average and standard deviation respectively.

2. "awareness programs are comprehensive", " 2.92 " and " 0.84 " are average and standard aviation respectively.

3. "awareness programs are good, " 2.97 " and " 0.81 " are average and standard deviation respectively.

4. "awareness program about preparedness are available", " 2.80 " and " 0.91 " are average and standard deviation respectively.

5. "awareness programs are enough", " 2.67 " and " 0.89 " are average and standard deviation respectively

6. Lastly "awareness programs about how to face disasters are available" " 2.65 " and " 0.95 " are average and standard deviation respectively.

It's important to explain the results of awareness factor according to individuals views (study sample), their evaluations standard (average) is " 2.87 " as shown in table (13).

Chi- square and correlations "C" experiment:

The second factor of the first hypothesis stated that "there is a significant difference between disasters management and awareness programs".

Because calculated chi - square "193.72" is more than table value " 9.48 " of chi-square, this means that the second factor of the hypothesis is acceptable.

Table 14: Correlation between awareness and disaster management

\begin{tabular}{|c|c|c|c|c|c|}
\hline & & & $\begin{array}{l}\text { awareness about different disaster are } \\
\text { available }\end{array}$ & $\begin{array}{l}\text { awareness programs } \\
\text { comprehensive }\end{array}$ & are \\
\hline \multirow[t]{4}{*}{ spearman's rho } & $\begin{array}{l}\text { correlation } \\
\text { (2.tailed) }\end{array}$ & coefficient sig. & 1.000 & $\begin{array}{l}469 * * \\
.000\end{array}$ & \\
\hline & $\mathrm{N}$ & & 535 & 353 & \\
\hline & $\begin{array}{l}\text { correlation } \\
\text { (2.tailed) }\end{array}$ & coefficient sig. & $\begin{array}{l}469 * * \\
.000\end{array}$ & 1.000 & \\
\hline & $\mathrm{N}$ & & 353 & 353 & \\
\hline
\end{tabular}

** Correlation is significant at the 0.01 level (2. Tailed)

Table 15: chi- square

\begin{tabular}{llll}
\hline & value & df & \\
\hline Person chi-square & 197.999 & 16 & Asymp. Sig. (2. Sided) \\
likelihood Ratio & 126.627 & 16 & .000 \\
linear - by - linear Association & 93.572 & 1 & .000 \\
N of Valid cases & 353 & .000 &
\end{tabular}

To explain the correlation between disaster management and awareness, correlation table (14) and chi-square table (15) reveal the significant effect of awareness on disaster management for the probable value of C " 0.00 " is best than " 0.05 ", which mean positive correlation, this because increment of awareness increase the standards of preparedness to manage disasters.

Thirdly: Training:

Training phrase are ranging from high degree - low degree

Table 16: Percentage distribution of the study sample - third factor "training"

\begin{tabular}{|c|c|c|c|c|c|c|c|c|}
\hline \multirow{3}{*}{$\begin{array}{l}\text { Phrase } \\
\begin{array}{l}\text { employee's are trained to be ready for } \\
\text { disasters }\end{array}\end{array}$} & \multicolumn{2}{|c|}{ very weak } & \multirow{2}{*}{$\begin{array}{l}\text { weak } \\
60\end{array}$} & \multirow{2}{*}{$\begin{array}{l}\text { average } \\
135\end{array}$} & \multirow{2}{*}{$\begin{array}{l}\text { high } \\
119\end{array}$} & \multirow{2}{*}{$\begin{array}{l}\text { very high } \\
35\end{array}$} & \multirow{2}{*}{$\begin{array}{l}\text { average } \\
3.34\end{array}$} & \multirow{2}{*}{$\begin{array}{l}\begin{array}{l}\text { standards } \\
\text { deviation }\end{array} \\
0.91\end{array}$} \\
\hline & $\mathrm{C}$ & 4 & & & & & & \\
\hline & $\%$ & 1.1 & 17 & 38.2 & 33.7 & 9.9 & & \\
\hline employee's are trained to use technology & $\mathrm{C}$ & 24 & 56 & 128 & 112 & 33 & 3.21 & 1.04 \\
\hline to face disasters & $\%$ & 6.8 & 15.9 & 36.3 & 31.7 & 9.3 & & \\
\hline employee's are trained about hypothetical & $\mathrm{C}$ & 13 & 83 & 132 & 89 & 36 & 3.15 & 1.01 \\
\hline disasters cases & $\%$ & 3.7 & 23.5 & 37.4 & 25.2 & 10.2 & & \\
\hline employee's of other sectors are trained to & $\mathrm{C}$ & 22 & 109 & 164 & 43 & 15 & 2.77 & 0.90 \\
\hline face disasters & $\%$ & 6.2 & 30.9 & 46.5 & 12.2 & 4.2 & & \\
\hline \multirow[t]{2}{*}{ training are comprehensive } & $\mathrm{C}$ & 9 & 71 & 182 & 70 & 21 & 3.07 & 0.86 \\
\hline & $\%$ & 2.5 & 20.1 & 51.6 & 19.8 & 5.9 & & \\
\hline \multirow[t]{2}{*}{ the standard of training programs is good } & $\mathrm{C}$ & 11 & 79 & 161 & 82 & 18 & 3.05 & 0.89 \\
\hline & $\%$ & 3.1 & 22.5 & 45.9 & 23.4 & 5.1 & & \\
\hline training factor & & & & & & & 3.1 & 0.71 \\
\hline
\end{tabular}

Source: made by the researcher - field study data -2015

According to the table, the ranking of training phrases comes as follow:

1. "employee's are trained to be ready for disaster", "3.34" and " 0.91 " are average and standard deviation.

2. "employee's are trained to use technology to face disasters", "3.21" and "1.04" are average and standard deviation respectively

3. "employee's are trained about hypothetical disasters cases", "3.15" and "1.01" are average and standard deviation respectively.

4. "training programs are comprehensive", "3.07" and " 0.86 " are average and standard deviation respectively.

5. "The standard of training programs is good", " 3.05 " and " 0.89 " are average and standard deviation respectively.

6. Lastly comes the phrase" employs of other sector are trained to face disaster", " 2.77 " and " 0.90 " are average and standard deviation respectively.

From the table its clear that individuals of the study sample evaluate training, their evaluation average is (3.1) degree.

Chi- square and correlation " $\mathrm{C}$ " experiment: 
The third factor of the first hypothesis of the study states that (there is a significant differences between disasters management and training) to know individuals "study sample" view, calculated chi-square (193.72) is compared with chi-square value from the table (9.48). this approve that there is significant differences between disaster management and training - the hypothesis is acceptable.

Table 17: Correlation

\begin{tabular}{lll}
\hline & $\begin{array}{l}\text { employee's trained about hypothetical disasters Employee's are trained to be ready to face } \\
\text { cases. }\end{array}$ & 1 \\
\hline correlation coefficient & $489^{* *}$ & 353 \\
sig. (2.tailed) & 0.000 & $489 * *$ \\
$\mathrm{~N}$ & 353 & 0.000 \\
correlation coefficient & 1 & 353 \\
sig. (2.tailed) & 353 & \\
$\mathrm{~N}$ & & \\
** Correlation is significant at the 0.01 level (2. Tailed)
\end{tabular}

Table 18: chi- square tests

\begin{tabular}{|c|c|c|c|}
\hline & value & df & Asymp. Sig. (2. Sided) \\
\hline Person chi-square & 109.782 & 16 & .000 \\
\hline like hood Ratio & 117.943 & 16 & .000 \\
\hline linear - by - linear Association & 84.322 & 1 & .000 \\
\hline $\mathrm{N}$ of Valid cases & 353 & & \\
\hline
\end{tabular}

Table (17) and (18) indicate that there is a positive correlation between disasters management and trainingbecause of the high correlation value (0.49), this because of the good training programs.

\section{Conclusions:}

According to factors results we can conclude that:

The first factor interested in evaluating risks analysis. However the study investigate the availability of data about risks zones and probability of risks occurrence, but it is not enough to approximate probable losses size and probable risk events, this because studies in this realm are few. Malky study results agree with this conclusions, but Alota by study in a contrast side which conclude that Saudi civil defense implements procedures of risks analysis which different from scientific standard and bases, Arm strong maintained that: risk analysis are important to determine future disasters, to find suitable solutions and to work out plans to prevent disasters or to mitigate its effects, this agree with Band study which recommends manufacturing safety programs, one of them is risks analysis in all industrial firms.

The second factor aims at evaluating awareness in different sectors, the study explains that awareness programs about how to face disasters are moderate"not high", this agree with malky study, and differ from Gurany two studies (2006), (2009) which approved weaknesses of awareness programs, this attributed to the lack of disaster units at some sectors - this leads to weak awareness of employee's about preparedness to manage disasters and how to deal with it, also this study not agree with Alboreeny study (1996) who stressed that employees lacks awareness and experience to deal with disasters.

The third factor investigate training of study sample individual, the study concludes that training is not high and not weak, its in a moderate way, because of the low common training "includes all sectors", this agree with Malky study (2011) and in contrast to Shamrany study (2009) and Gurany (2009) - this study is distinguished by the private sector participation, but Gurany (2009) and Aldoag (1997) who shows that employees training is weak, also Alboreeny study (1996) indicate weakness of employees training industrial safety.

\section{Recommendations:}

(1) It's imperative to raise risks analysis standards, especially to determine probability degree and losses size. (2) Increment of training programs about preparedness to deal with disasters. (3) Permanent increment of awareness programs for disaster management staff. (4) Establishment of a new geological and climate centers and stations to oversee environmental situations and to forecast about potential risks before occurrence. (5) Encouragement and increment of professional studies in disasters management, especially preparedness stage which is considered the backbone of disaster management. (6) Recommend to make more studies and researches about disaster management through support and encouragement to researchers.

\section{REFERENCES}

[1] Issues and Actins, 2009. "Reducing Disaster Risk through Science": The Full Report of the ISDR Scientific and Technical Committee (UN).

[2] Armstrong, Engineering: Plastic Development Management, Holistic Approach, Cambridge University, London, 2001.

[3] Brian, Jacobs, R 1899. relations between Different Levels of Boverment in Uriel Rosenthal: Crisis Management: an international perspective, Fireim, bruxelles.

[4] Davis, G and M. Margreth, 1985. Management information systems, New York, McGraw-Hill, inc.

[5] Svinivas, H., Y. Nakagawa, 2007. Environmental implications for disaster Preparedness: Lessons learnt from the Indian Ocean Tsunami, J.of Environmental Management, N0.89, pp: 4-13, Elsevier.

[6] Robert, F., 1986. when the crisis is terrorism: Security Management, 30.

[7] Banda, Hussain, 1998. Application of the Safety Management and Continuous Development Program, Research Presented at the 11th Industrial Security Symposium, Riyadh, Supreme Commission for Industrial Security.

[8] El-Borini, Haifa, 1996. The extent of readiness of industrial companies in the Arab Republic of Egypt to confront crises and radiological disasters, research presented to the first conference to confront crises and disasters, Ain Shams University, Cairo, 1996.

[9] Evaluation of Risk Analysis Procedures in the Kingdom of Saudi Arabia: An Applied Study on the General Directorate of Civil Defense, PhD Thesis, Naif Arab University for Security Sciences and Training, Riyadh, 2006.

[10] Al Salem, Ali, 2008. Preparedness for Crisis and Disaster Management, Unpublished Master Thesis, Naif Arab University for Security Sciences, Riyadh, 2008.

[11] Shammari, Fahid, 2002. The Creative Approach to Crisis and Disaster Management, Riyadh, Najd Press

[12] Tayeb, Hassan Abshar, 1992. Disaster Management, First Edition, Medlight Ltd., London.

[13] Al-Qarni, Abdullah, Mohammed, 2006. Foundations of Disaster Management, Riyadh, Al-Humaidhi Printing Press, First Edition.

[14] Al-Qarni, Abdullah, Mohammed, 2009. Evaluation of the Level of Disaster Preparedness Programs in Saudi Arabia, Research Presented at the International Symposium on Disaster Management, Riyadh, Saudi Arabia.

[15] Al-Qarni, Abdullah, Mohammed, 2006. Assessment of the Preparedness for Marine Disaster Management, Introduction to the Second Marine Disaster Symposium, Jeddah, Saudi Arabia. 
[16] Rampage, Abdulrahman and Ben Talib, Ibrahim, 1997. Evaluation of the Implementation of Civil Defense Committees in the Kingdom's Areas for the phases of Disaster Management in the Kingdom of Saudi Arabia: Reality and Perspective, Institute of Public Administration, Riyadh.

[17] Rampage, Abdul Rahman, 2003. Institute of Civil Defense, Emergency and Crisis Management Riyadh, Saudi Arabia.

[18] Taha, Hamid, 1992. Rescue and Rapid Intervention in Natural Disasters, (29th Scientific Symposium), Naif Arab University for Security Sciences, Riyadh.

[19] Al-Maliki, Abdul Rahman, 2011. The Role of Civil Defense in Enhancing Environmental Security and the Measures Taken Toward Seoul, Naif Arab University for Security Sciences, Riyadh.

[20] Abo El-Nasr, Medhat Mohamed, 1999. A Study on the Concept of Crisis from an Administrative and Social Perspective, Arab Journal for Security Studies and Training, No. 28, Naif Arab University for Security Sciences and Training, Riyadh.

[21] Al-Sheikh, Bader A. Mohsen, 2008. The readiness of security and safety departments to confront crises and disasters in the Royal Commission for Jubail and Yanbu, Master's study, Naif Arab University for Security Sciences and Training, Riyadh.

[22] El-Feki, Mohamed, 2000. Identification of the extent of implementation of crisis management in the Directorate General of Civil Defense in Riyadh, Master's study, Naif Arab University for Security Sciences and Training, Riyadh. 